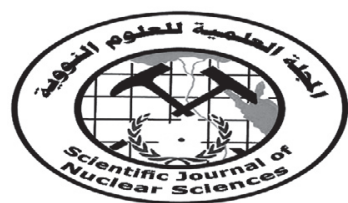

ISSN 2314-5609

Nuclear Sciences Scientific Journal vol. $1, \mathrm{p} 23-42$

2012

Nuclear Materials Authority

P.O.Box 530 Maadi, Cairo, Egypt

\title{
MINERALOGY OF THE RADIOACTIVE OCCURRENCE AT THE NORTHERN PERIPHERY OF GABAL GATTAR GRANITES, NORTH EASTERN DESERT, EGYPT.
}

\author{
SALAH S. ELBALAKSSY \\ Nuclear Materials Authority P.O. Box, 530, El Maadi, Cairo, Egypt.
}

\begin{abstract}
The northern periphery of G. Gattar granites is mineralogically studied. The study area exhibits significant potential for radioactive occurrences especially in the strongly altered granites at the intersection between the basic dykes striking $\mathrm{N} 30^{\circ} \mathrm{E}$ and a sinestral strike-slip fault trending N-S. These occurrences are mostly of epigenetic origin. They are closely associated with the hydrothermal alterations; hematitization, kaolinitization and episyenitization causing marked enrichment of some elements notably, Zr, Y, Zn, Ba and REEs. The uranium occurrences vary considerably in their contents from $68 \mathrm{ppm}$ to $4800 \mathrm{ppm}$, whereas the thorium contents reach up to $600 \mathrm{ppm}$ especially in the desilicified granites.

These radioactive occurrences may be due to the existence of some primary and secondary radioactive minerals. The primary minerals comprising uraninite and thorianite whereas the secondary ones including altered aggregated fragments of coffinite, becquerelite and gummite which were probably formed in the early stages due to uraninite dissolution. Furthermore, uranophane, kasolite, weeksite and autunite are the most conspicuous supergene uranium minerals which are mostly formed as a result of the extensive alterations of the pre-existing primary ones. The latter four minerals display mutual genetic association, hence, it is suggested that the heterogeneous hydrothermal solutions may play a crucial role in formation of the observed secondary U- minerals association in the northern part of Gattar granites pluton.
\end{abstract}


معدنية التواجدات الأشعاعية با لد الثمالى لجرانيتات جبل جتار شمال الصحراء الشرقيةـ مصر

صلاح صبحى البلاقصى

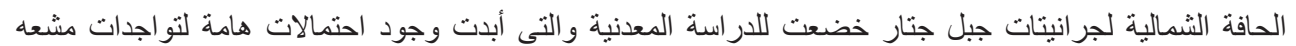

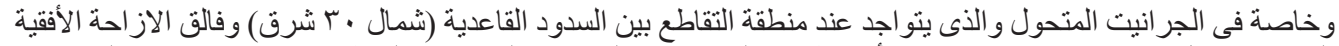

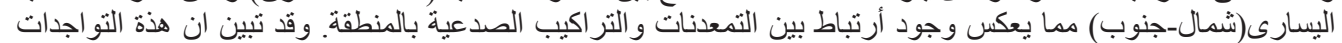

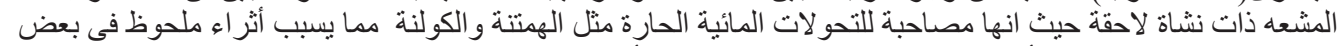

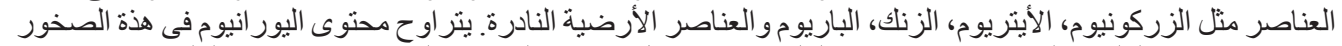

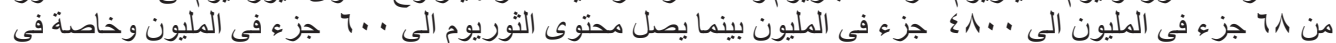

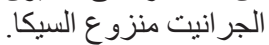

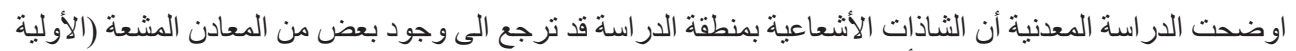

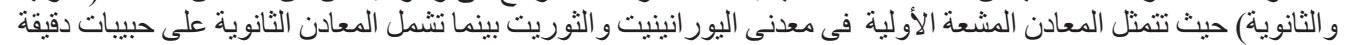

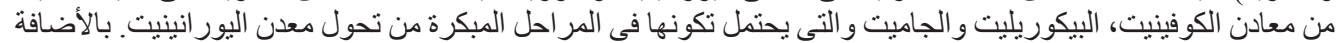

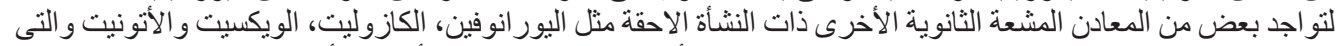

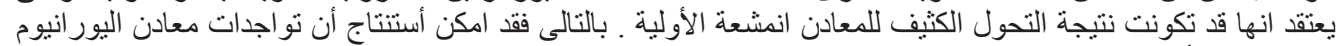
مصاحبة النشأة بالحافة الثمالية لجر انيتات جبل جتار يعكس دور المحاليل المائية الحارة الغير منجانسة. 